\title{
DINAMIKA POLITIK PENDIDIKAN AGAMA DI INDONESIA
}

\author{
Muhammad Bisyri \\ Pesantren Tahfidz Daarul Qur'an Tangerang \\ Email: m_bisyri_has@yahoo.com
}

\begin{abstract}
Abstact: Law No. 4/1950 Jo. Law No. 14/1954 stated that the purpose of education was to create a moral human being. It was interpreted that moral human being could be created not only through religion because the basis of moral was not always religion. Therefore, in the 1950s religion was not compulsorily taught at school. At later stage, as stipulated in Law No. 2/1989 that education was to create a complete human being devoting to God Almighty One, religion was a compulsory at school. The gap between these laws was that school with certain religion was not required to teach other different religions. This stipulation has later become problematic. In 2003, Law No 20 about national education system was enacted emphasizing the existence of religion education. This law mandated that religion was a compulsory in every education institution whereby the subject matters to be suited to the students and taught by the relevant teacher. It has been apparent that education has historically been improved from time to time.
\end{abstract}

Keywords: law, education of religion.

\begin{abstract}
Abstrak: Undang-Undang Nomor 4/1950 Jo. UU No. 14/1954 menyatakan bahwa tujuan pendidikan adalah untuk menciptakan manusia yang ber moral. Hal ini ditafsirkan bahwa manusia yang bermoral dapat diupayakan tidak hanya melalui agama karena dasar moral tidak selalu agama. Oleh karena itu, pada 1950-an agama tidak wajib diajarkan di sekolah. Pada tahap selanjutnya, sebagaimana diatur dalam UU No. 2/1989 pendidikan adalah untuk menciptakan manusia yang taat mengabdikan diri kepada Tuhan Yang Maha Esa, sehinnga pelajaran agama wajib diberikan di sekolah. Walaupun Kesenjangan undangundang tersebut adalah sekolah dengan agama tertentu seharusnya tidak diajarkan Agama yang berbeda dengan Agama yang ada di sekolah tersebut. Ketentuan ini kemudian menjadi bermasalah. Pada 2003, UU No 20 tentang sistem pendidikan nasional diberlakukan menekankan adanya pendidikan agama. Undang-undang ini mengamanatkan bahwa agama adalah wajib di setiap institusi pendidikan di mana materi yang akan diberikan kepada siswa yang akan diajarkan oleh guru yang bersangkutan. Sudah jelas bahwa pendidikan secara historis telah ditingkatkan dari waktu ke waktu.
\end{abstract}

Kata kunci: hukum, pendidikan agama.

\section{Pendahuluan}

Di dalam Pembukaan UUD 1945 disebutkan dengan jelas dan tegas bahwa salah satu amanat yang diemban oleh negara adalah mencerdaskan kehidupan bangsa, di samping melindungi segenap bangsa, melaksanakan ketertiban dunia yang berdasarkan kemerdekaan dan perdamaian abadi serta keadilan ${ }^{1}$. Apa yang dinyatakan dalam Pembukaan UUD 1945 sedikitnya memiliki dua makna. Pertama bahwa

\footnotetext{
1 Secara lengkap redaksi Pembukaan UUD 1945 yang dimaksud adalah secara khusus sebagaimana yang terdapat pada paragraf keempat.
}

dasar dari kehidupan bermasyarakat dan bernegara adalah nilai-nilai Pancasila. Kedua bahwa salah satu tujuan dalam membentuk negara Indonesia adalah mencerdaskan kehidupan bangsa. Bermula dari amanat yang terdapat dalam pembukaan UUD 1945 lahirlah kebijakan-kebijakan pemerintah yang erat kaitannya dengan usaha mencerdaskan kehidupan bangsa yang terimplementasi dalam kebijakan pendidikan.

Beberapa dari para pengkaji pendidikan di antaranya HAR Tilaar berpendapat bahwa pendidikan adalah suatu proses menumbuhkembangkan eksistensi peserta didik yang 
memasyarakat, membudaya, dalam tata kehidupan yang berdimensi lokal, nasional, dan global. Dari arti ini lazim disebutkan bahwa pendidikan adalah upaya untuk memanusiakan manusia. ${ }^{2}$ Dari pengkaji pendidikan lainnya, semisal al-Asfahani mengartikan istilah tarbiya (pendidikan) sebagai proses menumbuhkembangkan peserta didik yang dilakukan setahap demi tahap untuk mencapai kesempurnaan (had al-tamâm) dalam semua dimensinya. ${ }^{3} \quad$ Adapun istilah pendidikan sebagaimana tertuang dalam Undang-Undang Indonesia adalah usaha sadar dan terencana untuk mewujudkan suasana belajar dan proses pembelajaran agar peserta didik secara aktif mengembangkan potensi dirinya untuk memiliki kekuatan spiritual keagamaan, pengendalian diri, kepribadian, kecerdasan, akhlak mulia, serta keterampilan yang diperlukan dirinya, masyarakat, bangsa, dan negara. ${ }^{4}$

Keadaan pendidikan suatu negara sangat ditentukan oleh ideologi negara tersebut. Hal ini karena dalam menentukan setiap kebijakan, tak terkecuali kebijakan mengenai pendidikan, haluan politik dan ideologi sangat menentukan. Dengan begitu arah pendidikan di setiap negara akan sangat dipengaruhi oleh ideologi politik negara yang bersangkutan. Keadaan seperti ini membuktikan bahwa terdapat kaitan yang erat antara pendidikan dan politik. Plato di dalam Republic membahas hubungan antara pendidikan dan politik. Plato mendemontrasikan dalam buku tersebut bahwa sekolah adalah salah satu aspek kehidupan yang terkait dengan lembaga-lembaga politik. Plato menggambarkan adanya hubungan dinamis antara aktivitas

\footnotetext{
${ }^{2}$ Disarikan dari H.A.R. Tilaar, Pendidikan, Kebudayaan, dan Masyarakat Madani Indonesia, (Bandung: PT. Remaja Rosda Karya, 2002), h. 17-27.

${ }^{3}$ Hal ini sebagaimana disebutkan oleh Abdurrahman anNahlâwi, Ushulut at-Tarbiyat al-Islâmiyyah wa Asâlîbuha fi al-Bayt wa al-Madrasah al-Mujtama', (Beirut: Dar al-Fikr, 1979), h. 13.

${ }^{4}$ Bab I Ketentuan Umum Pasal 1 ayat 1 Undang-Undang Republik Indonesia Nomor 20 Tahun 2003 tentang Sistem Pendidikan Nasional.
}

pendidikan dan aktivitas politik. ${ }^{5}$ Selanjutnya David Abernethy dan Trevor Coombe berpandangan bahwa pendidikan dan politik terkait tanpa dapat dipisahkan. Lebih lanjut menurut mereka hubungan timbal balik antara pendidikan dan politik dapat terjadi melalui tiga aspek, yaitu pembentukan sikap kelompok (groups attitudes), masalah pengang-guran (unemployment), dan peranan politik kaum cendekia (the political role of the intelligentsia). ${ }^{6}$

Selain dari tokoh tersebut, tokoh lainnya yang berpendapat serupa adalah Roger Dale, Muchtar Buchori, ${ }^{8}$ HAR Tilaar, ${ }^{9}$ Noor Syam, ${ }^{10}$

\footnotetext{
${ }^{5}$ Hal itu adalah sebagaimana yang dikesankan oleh Allan Bloom dalam bukunya Closing of the American Mind, sebagaimana disebut oleh Sirozi dalam Politik Pendidikan: Dinamika Hubungan Antara Kepentingan Kekuasaan dan Praktik Penyelenggaraan Pendidikan, (Jakarta: PT RajaGrafindo, 2010), h. 7.

${ }^{6}$ David Abernethy dan Trevor Coombe, "Education and Politics in Developing Countries", Harvard Educational Review, Vol. 35, Nomor 3, 287-289.

7 Ia menyebutkan kontrol negara terhadap pendidikan umumnya dilakukan melalui empat cara. Pertama, sistem pendidikan diatur secara legal. Kedua, sistem pendidikan menekankan ketaatan pada aturan objektivitas. Ketiga, penerapan wajib belajar, dan keempat reproduksi politik ekonomi yang berlangsung di sekolah dalam konteks politik tertentu. Roger Dale, The State and Education Policy, (Milton Keynes UK: Open University Press, 1989), h. 39-43.

${ }^{8}$ Ia menegaskan bahwa politik tidak dapat terpisahkan dari pendidikan, kecuali jika suatu negeri ingin memiliki generasi yang buta politik, yang tidak dapat diharapkan untuk mengeluarkan negeri dari krisis. Buchori juga menegaskan bahwa politik adalah cara untuk mengelola lingkungan yang luas, bukan hanya perebutan kekuasaan, dan adalah tugas sekolah untuk membantu para pelajar agar dapat membedakan antara politik yang baik dan buruk. Pernyataan Buchori tersebut adalah sebagaimana termuat pada harian The Jakarta Post edisi 16 Maret 2001 yang memuat beberapa pikiran utama yang muncul dalam sebuah seminar. M. Sirozi, Politik Pendidikan Dinamika Hubungan Antara Kepentingan Kekuasaan dan Praktik Penyelenggaraan Pendidikan, (Jakarta: PT Raja Grafindo Persada, 2003), Cet. III, h. 30-31.

9 Tilaar berpandangan pendidikan dan politik memiliki keterkaitan, namun pendidikan tidak dapat menggantikan fungsi politik. Akan tetapi tanpa pendidikan tujuan-tujuan politik sulit terlaksana. Oleh karena itu, fungsi dan peranan pendidikan dalam kehidupan suatu bangsa tidak dapat dipisahkan dari kehidupan politik, ekonomi, hukum, dan budaya. H.A.R. Tilaar, Kekuasaan dan Pendidikan: Manajemen Pendidikan Nasional Dalam Pusaran Kekuasaan, h. 17-27.

10 Syam berpendapat negara sebagai lembaga nasional memiliki kewajiban untuk mewujudkan seluruh cita-cita nasional yang meliputi bidang politik, ekonomi, sosial,
} 
dan Sirozi. ${ }^{11}$. Lebih lanjut menurut Sirozi pendidikan dan politik adalah dua elemen penting dalam sistem sosial politik setiap negara. Keduanya saling mendukung dalam proses pembentukan karakteristik masyarakat di suatu negara. Lembaga dan proses pendidikan memiliki peran penting dalam membentuk perilaku politik masyarakat, dan adapun lembaga dan proses politik di suatu negara membawa dampak besar terhadap karakteristik pendidikan. Ada hubungan erat dan dinamis antara pendidikan dan politik. ${ }^{12}$ Walaupun terdapat tokoh lainnya yang menentang kaitan antara politik dan pendidikan, namun secara faktual tidak dapat disangkal bahwa pendidikan memiliki kaitan dengan politik. ${ }^{13}$

pertahanan keamanan, kebudayaan dan pendidikan. Untuk menjamin kontinuitas eksistensi bangsa, juga demi identitas serta tujuan nasional maka pendidikan adalah lembaga yang paling efektif. Karena itulah negara mengatur pelaksanaan sistem pendidikan nasional. Lebih lanjut Noor Syam menyebutkan bahwa demi kemerdekaan, integritas wilayah dan kehormatan bangsa, maka tiap bangsa melakukan segala usaha menentang ekspansi, dominasi politik maupun ekonomi, dan usaha yang paling efektif untuk semua tujuan tersebut adalah pendidikan. Mohammad Noor Syam dalam Filsafat Pendidikan dan Dasar Filsafat Pendidikan Pancasila, (Surabaya: Usaha Nasional, 1988), Cet. Ke 4, h. 207.

${ }^{11}$ Sirozi menyebut bahwa berbagai persoalan pendidikan yang ada di berbagai negara berkembang, termasuk di Indonesia, tidak mungkin dapat dipahami jika hanya dilihat dari perspektif pembelajaran semata, tetapi perlu juga dilihat dari perspektif sosial dan politik. M. Sirozi, Politik Pendidikan Dinamika Hubungn antara Kepentingan Kekuasaan dan Praktik, h. 9 .

12 Salah satu contoh kaitan pendidikan dengan politik sebagaimana disebut Sirozi misalnya organisasi Persatuan Guru Republik Indonesia (PGRI) yang semasa era Orde Baru (19661998) menjadi “anak manis” penguasa, sekarang cukup kritis terhadap berbagai kebijakan pendidikan di Indonesia, terutama kebijakan yang ada kaitannya dengan nasib dan profesi guru. M. Sirozi, Politik Pendidikan: Dinamika Hubungan Antara Kepentingagn Kekuasaan dan Praktik Penyelenggaraan Pendidikan, (Jakarta: PT RajaGrafindo, 2010), h. 1. Selanjutnya Soedijarto memberikan contoh kemenangan John Kerry dalam pemilihan calon presiden Partai Demokrat di Iowa dan New Hamphsire karena dalam kampanyenya ia bertekad untuk kembali memperhatikan pendidikan dan kesehatan. Soedijarto, Landasan dan Arah Pendidikan Nasional Kita, (Jakarta: Penerbit Kompas, 2008), h. 347.

${ }^{13}$ Dari mereka yang menolak keterkaitan politik dengan pendidikan antara lain Thomas H. Eliot dan Roesco Martin.
Sirozi menyebutkan bahwa kaitan politik dengan pendidikan sangat bergantung pada kondisi masyarakatnya, sehingga dalam suatu masyaraka tertentu hubungan tersebut boleh saja sangat kuat dan riil, dan dalam masyarakat yang lain hubungan tersebut lemah dan tidak nyata. ${ }^{14}$ Di negara demokrasi seperti Indonesia, walaupun kewajiban utama penyelenggara pendidikan adalah negara, akan tetapi dalam batas-batas tertentu negara memberikan konsesi kepada warga negara, untuk menyelenggarakan pendidikan. Hal ini berbeda dengan negaranegara yang tidak menggunakan sistem demokrasi, misalnya otoriter ${ }^{15}$ maka semua pendidikan diselenggarakan oleh negara. ${ }^{16}$

Thomas H. Eliot berpandangan bahwa semua sistem sekolah telah dirusak oleh berbagai aspek politik yang masuk secara paksa, khususnya penggunaan patronase dalam pengangkatan (staf) dan penentuan kontrak-kontrak kerja dengan mengabaikan kemungkinan pendidikan yang terbaik bagi anakanak. Pandangan Eliot tersebut di Amerika mula-mula dikembangkan oleh para administrator sekolah dan para pendidik professional yang ingin melindungi pendidikan publik dari politik lokal dan nasional Amerika awal abad ke-19 yang berwatak korup dan kejam. Thomas H. Eliot, Towards an Understanding of Public School Politics, dalam American Political Science Review, Vol. 53, No. 4, Desembe 1957, h: 1032-1051. Roesco Martin yang sejalan dengan pandangan Eliot, memandang bahwa infiltrasi politik dalam dunia pendidikan adalah sesuatu yang berbahaya. Lebih lanjut Martin berpandangan bahwa pendidikan publik harus dipisahkan (dari politik) dan mendapat perlakuan khusus. Sirozi dalam Politik Pendidikan: Dinamika Hubungan Antara Kepentingagn Kekuasaan dan Praktik, h. 21-23.

${ }^{14}$ M. Sirozi, Politik Pendidikan Dinamika Hubungn antara Kepentingan Kekuasaan dan Praktik, h. 9.

${ }^{15}$ M. Carter dan John H. Herz mencirikan demokrasi dan otoriter dalam gambaran yang kontradiktif. Menurutnya demokrasi liberal ditandai oleh adanya pembatasan-pembatasan terhadap pemerintah untuk memberikan perlindungan bagi individu dan kelompok dengan menyusun pergantian pimpinan secara berkala, tertib, dan damai melalui alat perwakilan rakyat yang efektif. Sebaliknya totaliterisme ditandai oleh dorongan negara untuk memaksakan persatuan, usaha menghapus oposisi terbuka dengan suatu pimpinan yang dirinya merasa paling tahu mengenai cara-cara menjalankan kebijaksanaan pemerintah, dan pimpinan tersebut menjalankan kekuasaan melalui suatu elit yang kekal. Sebagaimana disebut Moh. Mahfudz MD, Politik Hukum Di Indonesia, (Jakarta: PT Raja Grafindo Persada, 2012), h: 23-24.

${ }^{16}$ Mohammad Noor Syam dalam Filsafat Pendidikan dan Dasar Filsafat Pendidikan Pancasila, h. 219. 
Pada dasarnya politik menurut M. Noor Syam adalah usaha untuk menentukan peraturan-peraturan yang dapat diterima baik oleh sebagian besar warga, untuk membawa masyarakat ke arah kehidupan bersama yang harmonis. Usaha untuk mencapai kehidupan yang baik ini menyangkut bermacam-macam kegiatan yang di antaranya menyangkut proses penentuan tujuan dari sistem, serta cara-cara melaksanakan tujuan itu. Dari sini diperlukan kekuasaan dan wewenang. ${ }^{17}$ Adapun politik pendidikan dapat dipahami sebagai bidang kajian mengenai hubungan antara proses munculnya berbagai tujuan pendidikan dan cara-cara pencapaiannya. Kajian politik pendidikan terfokus pada peranan negara dalam bidang pendidikan, sehingga dapat menjelaskan pola, kebijakan, dan proses pendidikan serta berbagai asumsi, maksud, dan outcome dari berbagai strategi perubahan pendidikan dalam suatu masyarakat secara lebih baik. ${ }^{18}$

Sejak Indonesia menyatakan kemerdekaannya, telah lahir berbagai kebijakan yang berkaitan dengan pendidikan. Hal ini menunjukkan bahwa negara memperhatikan masalah pendidikan. Namun produk peraturan mengenai pendidikan menjadi kontra produktif manakala kebijakan-kebijakan tersebut justeru mengaburkan arah dari tujuan pendidikan itu sendiri. Hal ini adalah sebagaimana menurut Winarno Surakhmad bahwa sebanyak 25 menteri pendidikan sampai tahun 2012, sejak dirintis oleh Ki Hajar Dewantara sebagai Menteri Pengajaran yang pertama, arah dan strategi pendidikan nasional sampai saat ini masih berbeda-beda, selau berubah-ubah, dan bahkan

\footnotetext{
${ }^{17}$ Dalam menentukan tatanan sosial yang baik akan sangat dipengaruhi oleh persepsi yang baik dan adil, dan hal ini dipengaruhi oleh nilai-nilai serta ideologi masing-masing dan jaman yang bersangkutan. Miriam Budiardjo, Dasar-Dasar Ilmu Politik, (Jakarta: Gramedia Pustaka Utama, 2010), Edisi Revisi Cet. IV, h. 13-15.

${ }^{18}$ M. Sirozi, Politik Pendidikan: Dinamika Hubungan Antara Kepentingan Kekuasaan dan Praktik, h. 9.
}

sangat bertentangan. ${ }^{19}$ Winarno juga menyebut bahwa di kalangan masyarakat luas mengenal ungkapan "ganti menteri ganti kebijakan". ${ }^{20}$

Sejatinya pendidikan yang dilangsungkan di mana pun harus sesuai dengan kondisi religiososio-kultur tempat di mana pendidikan dilangsungkan. Sehingga produk pendidikan yang dihasilkan akan dapat memasyarakat, membudaya, sesuai dengan konteks yang ada. Kaitannya dengan itu, menjadi hal yang penting untuk mengkaji perundang-undangan yang berkaitan dengan dinamika politik pendidikan agama di Indonesia mengingat masyarakat Indonesia adalah masyarakat dengan dasar negara yang pertamanya adalah Ketuhanan Yang Maha Esa. Tulisan ini mengkaji secara historis sosiologis terhadap politik kebijakan pendidikan agama di Indonesai. Kajian ini mengungkap bagaimana perubahan-perubahan kebijakan mengenai pendidikan agama.

\section{Pembahasan}

Berkenaan dengan dinamika pendidikan Indonesia secara umum, Van der Kroef memberikan kategorisasi fase perkembangan pendidikan Indonesia dalam tiga fase. Fase pertama adalah fase di mana bangsa Indonesia belum mengenal metode yang dilangsungkan di negara-negara Barat, sehingga aktivitas pendidikan semuanya berdasar pada keaslian budaya masyarakat nusantara. Fase yang kedua adalah fase saat bangsa Indonesia berada dalam koloni Belanda maupun Jepang. Pada saat ini bangsa Indonesia mulai mengenal dan membangun model pendidikan lebih modern dibanding fase sebelumnya. Selanjutnya adalah fase nasional yang dimulai dari keberhasilan

\footnotetext{
19 Winarno Surakhmad dalam Sambutan pada buku Kaleidoskop Pendidikan Nasional. Kumpulan artikel HAR Tilaar (Jakarta: Kompas Media Nusantara, 2012) XXI-XXII.

20 Winarno Surakhmad dalam Sambutan pada buku Kaleidoskop Pendidikan Nasional.
} 
bangsa Indonesia mengusir penjajah sampai sekarang. ${ }^{21}$

Fase pertama praktik pendidikan agama di nusantara terimplementasi melalui lembagalembaga pendidikan semisal pesantren yang notabenenya merupakan lanjutan dari pendidikan agama Hindu-Budha. Pada tahapan ini hampir seluruh lembaga pendidikan pesantren memokuskan pembelajarannya pada keilmuan agama Islam tanpa disertai pengetahuan dan keterampilan hidup lainnya. Fase ke dua dunia pendidikan agama semisal pesantren mulai bersentuhan dengan pendidikan model Barat yang dibawa oleh kolonial Belanda. Pada fase kedua ini pesantren bersinggungan dengan pendidikan Barat, sehingga pesantren mulai membuka diri misalnya dengan memasukkan ilmu-ilmu baru ke dalam materi belajarnya. Pada skala yang lebih luas, adanya perjumpaan budaya (cultural encounter) negaranegara berpenduduk muslim dengan Barat, melalui imperialisme dan kolonialisme, mendorong penguasa politik bekerjasama dengan tokoh-tokoh muslim setempat untuk melakukan transformasi dan modernisasi pendidikan Islam. Menurut Arif Subhan tema utama transformasi pendidikan Islam adalah memasukkan ilmu pengetahuan dan sains modern, termasuk bidang-bidang administrasi dan kemiliteran sebagai bagian dari materi yang diajarkan dalam pendidikan Islam. Perubahan juga terjadi pada tingkat kelembagaan, sistem dan metodologi

\footnotetext{
21 Van der Kroef, Education in Indonesia (artikel) dalam Problems and Promises of Education in Asia (Amerika Serikat: Phi Delta Kappa International, 1957), (diakses 10 September 2012). Tanpa mengingkari hal-hal baik yang di dalamnya, penulis berpendapat bahwa pendidikan pada masa kolonial Belanda dan Jepang adalah justru pendidikan yang tidak sebenarnya. Karena pada masa-masa tersebut, pendidikan diberikan kepada segenap masyarakat Indonesia bukan dengan tujuan pendidikan yang sebenarnya, yakni memanusiakan manusia. Akan tetapi pendidikan dilangsungkan justru untuk dieksplotasi dengan cara mempekerjakan para lulusan sekolah dengan gaji yang sangat rendah.
}

pembelajaran dan pandangan tentang hakikat pendidikan. $^{22}$

Pada fase yang ketiga, fase yang dimulai dari Indonesia merdeka sampai sekarang, bangsa Indonesia telah melahirkan tiga produk UndangUndang yang mengatur pendidikan nasional Indonesia. Ketiga Undang-Undang tersebut adalah Undang-Undang Nomor 4 Tahun 1950 jo. Undang-Undang Nomor 12 Tahun 1954 Tentang Pendidikan dan Pengajaran, selanjurnya Undang-Undang Nomor 2 Tahun 1989 tentang Sistem Pendidikan Nasional, dan yang terakhir adalah Undang-Undang nomor 20 Tahun 2003 tentang Sistem Pendidikan Nasional. Setiap UU tersebut lahir dalam suatu konteks tertentu baik politik, sosial, ekonomi, agama, dan konteks lainnya. Adanya perbedaan konteks yng melingkupi menjadikan produk UU yang berbeda pula.

\section{Politik Pendidikan Agama Pra- Kemerdekaan}

Pada masa kolonial Belanda, praktik pendidikan Islam telah lama berlangsung di pesantren-pesantren. Pada saat itu pesantren sepenuhnya merupakan lembaga untuk mengajarkan agama Islam, dan sangat sedikit pesantren yang memberikan pengajaran tentang keterampilan hidup. Maraknya praktik pendidikan Islam di nusantara antara lain didorong oleh tokoh-tokoh muslim nusantara yang memiliki semangat tinggi dalam mencerdaskan kehidupan masyarakat. Lebih lanjut dari itu adalah adanya organisasi-organisasi sosial kemasyarakatan yang berbasis agama semakin meneguhkan praktik pendidikan di nusantara. Muhammadiyah (berdiri tahun 1912) dan Nahdlatul Ulama (berdiri tahun 1926) merupakan dua organisasi besar yang sejak awal memberikan perhatian besar terhadap masalah

\footnotetext{
${ }^{22}$ Arif Subhan, "Lembaga Pendidikan Islam Indonesia Abad Ke-20: Pergumulan antara Modernisasi dan Identitas", dalam Disertasi, Sekolah Pascasarjana Universitas Islam Negeri Syarif Hidayatullah Jakarta tahun 2007, h. 1.
} 
pendidikan. Muhammadiyah dikenal sebagai organisasi Islam yang mengusung ide-ide modern sehingga dari awal Muhammadiyah memprakarsai praktik-praktik pendidikan yang mengakomodasi praktik pendidikan Barat. Adapun Nahdlatul Ulama dalam kajian Islam Indonesia sering disebut sebagai organisasi Islam tradisional dalam melakukan modernisasi di bidang pendidikan dilakukan secara pelan-pelan dan tidak pernah mengambil keputusan yang revolusioner karena dikhawatirkan menimbulkan reaksi keras dari tokoh pesantren (Kyai) dan masyarakat muslim. ${ }^{23}$

Pada mulanya praktik pendidikan yang berlangsung di pesantren-pesantren hanya mempelajari ilmu-ilmu keislaman tanpa disertai ilmu pengetahuan dan sains modern. Melihat hal itu, dalam catatan van der Chijs, Gubernur Jenderal van der Capellen memerintahkan untuk mengadakan penelitian tentang pendidikan masyarakat Jawa dengan tujuan meningkatkan kemampuan membaca dan menulis di kalangan masyarakat Jawa. Secara khusus diteliti juga apakah sebaiknya guru yang ada dimanfaatkan dan diberi motivasi melalui peraturan yang sesuai, atau perlu menciptakan suatu keadaan yang berbeda sama sekali. ${ }^{24}$

Tokoh pertama dari kalangan pemerintah Kolonial Belanda yang secara penuh bekerja untuk pendidikan orang bukan Eropa adalah Inspektur Pendidikan Pribumi yang pertama, J. A. Van der Chijs. Pada tahun 1865 dia menolak menyesuaikan pendidikan Islam yang ada. Alasan utamanya adalah karena ia berpandangan bahwa dalam praktik pendidikan Islam yang berlangsung di pesantren terdapat kebiasaan yang jelek. Kebiasaan jelek yang dimaksud adalah metode membaca teks Arab yang hanya dihafal tanpa pengertian dan pendalaman yang memadai.

${ }^{23}$ Karel A. Steenbrink, Pesantren, Madrasah, Sekolah: Pendidikan Islam dalam Kurun Modern, (Jakarta: LP3ES, 1986), h. 69.

${ }^{24}$ Hal ini sebagaimana dikutip oleh Karel A. Steenbrink dalam Pesantren Madrasah Sekolah, h. 1.
Pada saat bersamaan, di Minahasa dan Maluku terdapat sejumlah sekolah yang didirikan dan dikelola oleh zending, tetapi mendapat subsidi dari pemerintah. Sekolah-sekolah ini hampir semuanya memusatkan diri pada pendidikan agama. Van der Chijs setelah mengadakan perjalanan ke daerah tempat beradanya sekolah binaan zending pada tahun 1867, ia menyimpulkan bahwa kedudukan sosial orang-orang tersebut masih bersifat mendua. Bahkan dalam tempo agak cepat, Van der Chijs mengusulkan agar mutu pelajaran umum di sekolah-sekolah zending tersebut ditingkatkan, sedangkan pelajaran agama dikurangi. ${ }^{25}$ Menurut Sirozi, ancaman kebijakan pendidikan Belanda di dalam koloni tidak hanya bersifat pendidikan tetapi juga agama, hal ini dikarenakan bangsa Eropa menyatukan program pendidikannya dengan misi para imamnya. Sebagai akibatnya pemimpin muslim menghadapi dua tantangan sekaligus: westernisasi pendidikan dan penggunaan pendidikan untuk kristenisasi. ${ }^{26}$

Pada perkembangan selanjutnya sekolahsekolah zending ini akhirnya masuk ke dalam sistem pendidikan umum Gubernamen. Secara teknis memasukkan sekolah-sekolah zending tersebut ke dalam sistem sekolah umum lebih mudah daripada memasukkan pesantren ke dalam sistem pendidikan umum. Hal yang demikian ini antara lain karena siswa di sekolah binaan zending sudah diajar baca tulis huruf Latin, di samping juga sudah diajarkan ilmu hitung $^{27}$. Selain dari pada itu, pada tahun 1888 Menteri Kolonial menolak memberikan subsidi kepada sekolah-sekolah Islam (pesantren) karena campur tangan Gubernur Jenderal yang tidak mau mengorbankan keuangan negara untuk sekolah-sekolah tersebut. Semenjak itu sekolah Islam (pesantren) mengambil jalannya sendiri

\footnotetext{
${ }^{25}$ Karel A. Steenbrink, Pesantren Madrasah Sekolah, h. 4-5.

26 Muhammad Sirozi, Politik Kebijakan Pendidikan di Indonesia: peran tokoh-tokoh Islam dalam penyusunan UU No. 2 tahun 1989, (Jakarta: INIS, 2004), h. 36.

${ }^{27}$ Karel A. Steenbrink, Pesantren Madrasah Sekolah, h. 6.
} 
dan lepas dari Gubernamen, serta tetap berpegang pada tradisinya sendiri.

Perlakuan pemerintah Kolonial kepada pesantren yang notabenenya merupakan sekolah Islam sangat mungkin didasarkan atas anggapan buruk mereka mengenai pesantren. Pandangan beberapa ahli Islam Indonesia ketika mengkaji pesantren sering menghasilkan kesimpulan yang berkonotasi negatif. Semisal Clifford Geertz menggambarkan kehidupan keagamaan pesantren hanya berkisar pada kehidupan akhirat yang bertujuan untuk memperoleh pahala dan lebih bayak berpikir tentang nasib mereka setelah dikubur. Geertz menuliskan bahwa kehidupan pesantren hanya berkisar kepada "kuburan dan ganjaran”. 28 Selain Geertz, Alan Samson dalam kajiannya menyebutkan bahwa wajah pesantren digambarkan sebagai penganut suatu sistem keagamaan campuran elemen-elemen animisme, Hindu-Budhistis dan Islam, sama dengan wajah keagamaan orang abangan. ${ }^{29}$

Menurut Zamakhsyari Dhofier, karya-karya tentang pesantren yang pernah ditulis oleh para ahli tentang Islam Indonesia sering tidak memuaskan. Menurutnya, karya Geertz dalam beberapa tulisannya tentang pesantren tidak tegas

\footnotetext{
${ }^{28}$ Clifford Geertz, "The Javanese Kyai: The Changing Role of A Cultural Broker", dalam Comparative Studies in Society and History, Vol. 2 (1959-1960), p. 236-238.

29 Masyarakat Jawa menurut Clifford Geerts dikategarisasikan ke dalam tiga golongan, yakni santri, abangan, dan priyayi. Kelompok santri digunakan untuk mengacu pada orang muslim yang mengamalkan ajaran agama sesuai dengan syariat Islam. Kelompok abangan merupakan golongan penduduk Jawa muslim yang mempratikkan Islam dalam versi yang lebih sinkretis bila dibandingkan dengan kelompok santri yang ortodoks dan cenderung mengikuti kepercayaan adat yang didalamnya mengandung unsur tradisi Hindu, Budha, dan Animisme. Sedangkan kelompok priyayi digunakan sebagai istilah orang yang memiliki tingkat sosial yang lebih tinggi atau sering disebut kaum bangsawan. Namun penggolongan ketiga kategorisasi ini tidaklah terlalu tepat, karena pengelompokkan priyayi \& non priyayi adalah berdasarkan garis keturunan seseorang, sedangkan pengelompokkan santri - abangan dibuat berdasarkan sikap dan perilaku seseorang dalam mengamalkan agamanya (Islam). Dalam realitas, ada priyayi yang santri dan ada pula yang abangan, bahkan ada pula yang bukan muslim. Alan Samson, "Islam in Indonesia Politics", dalam Asian Survey, No. 8, p. 1001-1007.
}

dan saling bertentangan satu sama lain. Hal ini terjadi karena pesantren tidak dikaji dalam kerangka atau lingkungan sosial, ekonomi, serta politik para Kyai serta masyarakat secara keseluruhan dan tidak dianalisis mengenai latar belakang pesantren yang terpaksa berkembang seperti itu terutama setelah Islam Indonesia gagal mempertahankan kemerdekaannya dari kolonisasi Eropa disebabkan kalah dalam teknologi dan taktik serta strategi peperangan modern. ${ }^{30}$

Sekolah Islam yang di jaman kolonial Belanda dianggap tidak kompeten melangsungkan praktik pendidikan yang diinginkan Belanda, secara terus menerus berkembang sesuai dengan dinamika yang dikreasikan oleh masing-masing sekolah Islam. Menurut Steenbrink, sistem pendidikan umum di Indonesia bukanlah timbul sebagai hasil penyesuaiannya dengan sistem pendidikan Islam tradisional (pesantren). Sebaliknya sistem pendidikan Islam lama kelamaan akan menyesuaikan diri dan masuk ke dalam sistem pendidikan umum. $^{31}$ Abuddin Nata menyebutkan bahwa pendidikan agama pada masa prakemerdekaan selain tidak diakui dalam sistem pendidikan ia juga dianggap sebagai tempat menghasut dan melawan penjajah. Pendidikan agama memiliki momentum untuk dapat berkembang secara lebih luas beberapa waktu setelah kemerdekaan diraih oleh bangsa Indonesia. ${ }^{32}$

Langkah modernisasi pendidikan Islam yang ditempuh Muhammadiyah memiliki pengaruh penting dalam perkembangan pendidikan Islam di Indonesia. Konsep "HIS met de Qur'an", ciri khas Muhammadiyah, yang dapat diartikan sebagai "sekolah umum plus mata pelajaran

${ }^{30}$ Zamakhsyari Dhofier, Tradisi Pesantren: Studi Pandangan Hidup Kyai dan Visinya Mengenai Masa Depan Indonesia, (Jakarta: LP3ES, 2011), h. 12-13.

${ }^{31}$ Karel A. Steenbrink dalam Pesantren Madrasah Sekolah, h. 7 .

32 Abuddin Nata, Kapita Selekta Pendidikan Islam, (Jakarta: Penerbit Angkasa Bandung, 2003), h. 50. 
keislaman" menjadi model bagi lembaga-lembaga pendidikan. Sebagai implikasi, meskipun gagasan awal sekolah Islam yang menambahkan mata pelajaran keislaman dalam sistem kelembagaan dan kurikulum "sekuler" muncul di lingkungan Muhammadiyah, diseminasi sistem kelembagaan ini merambah kelompok-kelompok kelas menengah Muslim di perkotaan secara keseluruhan. Kelompok "santri baru" ini yang merupakan akibat dari keberhasilan pembangunan ekonomi dan proyek pendidikan Orde Baru merupakan kelompok yang paling banyak mendirikan sekolah-sekolah Islam yang merujuk konsep Muhammadiyah. ${ }^{33}$

Di lingkungan NU, ideologi keagamaan ahl Sunnah wa al-jamâah memiliki posisi sentral dalam organisasi. NU sendiri pada mulanya dimaksudkan sebagai gerakan yang bertendensi mempertahankan ideologi keagamaan tersebut dari kritisisme kaum Muslim reformis. Karena posisi ideologi keagamaan ahl Sunnah wa aljama'ah yang demikian sentral, NU menjadikan pesantren sebagai semacam "guardian of the faith". Oleh karena itu, dalam konteks modernisasi pendidikan Islam kalangan pimpinan NU yang sekaligus pimpinan pesantren bersikap hati-hati. Mereka mengadopsi modernisasi sejauh mendukung ideologi keagamaan sentral tersebut. ${ }^{34}$

Melalui modernisasi yang dilaksanakan di lembaga-lembaga pendidikan Islam, baik yang diprakarsai Muhammadiyah, NU, maupun organisasi keagamaan lainnya lambat laun pendidikan Islam dapat melahirkan generasi penerus yang dapat memerankan peranan besar baik dalam kancah nasional maupun internasional. Sesuai dengan kecenderunganya masing-masing semua lembaga pendidikan Islam dapat bergerak ke arah kemajuan yang dikehendaki.

\footnotetext{
${ }^{33}$ Arif Subhan, "Lembaga Pendidikan Islam Indonesia Abad Ke-20, h. 2.

${ }^{34}$ Arif Subhan, "Lembaga Pendidikan Islam Indonesia Abad Ke-20”, h. 2.
}

\section{Politik Pendidikan Agama Pasca Kemerdekaan}

Setelah proklamasi kemerdekaan Indonesia tanggal 17 Agustus 1945, maka perubahanperubahan tidak hanya terjadi dalam bidang pemerintahan saja, tetapi juga dalam bidang pendidikan. Menurut Ary H. Gunawan perubahan yang terjadi adalah perubahan yang menyangkut penyesuaian kebijakan pendidikan dengan dasar dan cita-cita bangsa dan negara Indonesia yang merdeka. Lebih jauh Gunawan menyebutkan bahwa perubahan dalam bidang pendidikan terutama dalam landasan ideal, tujuan pendidikan, sistem persekolahan, dan kesempatan belajar yang dapat diberikan kepada seluruh rakyat Indonesia. ${ }^{35}$ Setelah kemerdekaan lembaga pendidikan Islam kembali mengalami gelombang modernisasi. Departemen Agama, Muhammadiyah, NU, dan lembaga-lembaga independen merupakan aktor-aktor penting dalam modernisasi pendidikan Islam setelah kemerdekaan.

Dari waktu ke waktu, sejak Indonesia menyatakan kemerdekaannya, terdapat perubahan kebijakan dalam bidang pendidikan. $\mathrm{Hal}$ ini dapat ditelusuri misalnya ketika bangsa Indonesia memproklamasikan kemerdekaannya pada 17 Agustus 1945 ada keinginan di kalangan para pendidik nasional untuk menggabungkan ketiga unsur yang ada dalam pendidikan rakyat pada masa itu. Ketiga unsur yang dimaksud adalah unsur budaya setempat, unsur agama, dan pengetahuan Barat. ${ }^{36}$

Rencana sebagaimana tersebut $\mathrm{di}$ atas disusun oleh sebuah panitia kecil yang menjadi bagian dari Badan Usaha Persiapan Kemerdekaan Indonesia (BPUPKI) dan diketuai oleh Ki Hajar Dewantara. Oleh panitia kecil ini pendidikan agama disepakati untuk diberikan di sekolahsekolah yang diselenggarakan pemerintah.

\footnotetext{
35 Ary H. Gunawan, Kebijakan-Kebijakan Pendidikan di Indonesia, (Jakarta: Bina Aksara, 1986), h.32

${ }^{36}$ Anwar Jasin, Pembaharuan Kurikulum Sekolah Dasar: Sejak Proklamasi Kemerdekaan, (Jakarta:Balai Pustaka, 1987) h. 59.
} 
Sebenarnya pendidikan agama pada masa pendudukan Jepang dapat diselenggarakan di sekolah namun hanya di wilayah Sumatera bagian Barat, dan tidak diperbolehkan di wilayah lain. Pendidikan agama dapat diselenggarakan di semua sekolah pemerintah dimulai setelah kesepakatan yang lahir dari tim kecil tersebut. Pada saat itulah pendidikan nasional Indonesia mulai meninggalkan sifat sekulernya, dalam artian bahwa sistem pendidikan di Indonesai sudah mengakomodasi pelajaran agama untuk diajarkan di sekolah pemerintah. Hal ini adalah sesuai dengan dasar negara Pancasila yang sila pertamanya tentang Ketuhanan. ${ }^{37}$

\section{Undang-Undang Nomor 4 Tahun 1950 Undang-Undang Nomor 12 Tahun 1954 Tentang Pendidikan dan Pengajaran}

Setelah Indonesia merdeka, pendidikan agama telah mendapat perhatian serius dari pemerintah, baik di sekolah negeri maupun swasta. Usaha tersebut dimulai dengan memberikan bantuan sebagaimana anjuran Badan Pekerja Komite Nasional Pusat (BPKNP) tanggal 27 Desember 1945, disebutkan bahwa Madrasah dan pesantren yang pada hakikatnya adalah satu sumber pendidikan dan pencerdasan rakyat jelata yang telah berurat dan berakar dalam masyarakat Indonesia pada umumnya, hendaknya mendapatkan perhatian dan bantuan nyata berupa tuntunan dan bantuan material dari pemerintah.

Sejak Agustus 1950 penyelenggaraan pendidikan dan pengajaran menggunakan UU no. 4 tahun 1950 tentang Pokok Pendidikan dan Pengajaran. Susunan sekolah terdiri dari Sekolah Rakyat 6 tahun, Sekolah Lanjutan Tingkat Pertama 3 tahun dan Sekolah Lanjutan Tingkat Atas 3 tahun. Untuk memenuhi guru Sekolah Rakyat didirikan SGB (Sekolah Guru Bawah) 3 tahun dan SGA (Sekolah Guru Atas) 6 tahun. Selajutnya pada tahun 1954 didirikan lembaga

\footnotetext{
${ }^{37}$ Anwar Jasin, Pembaharuan Kurikulum Sekolah Dasar, h. 59.
}

pendidikan guru setingkat Universitas yang pertama disebut Perguruan Tiggi Pendidikan Guru (PIPG) di Bandung. ${ }^{38}$ Didirikannya beberapa lembaga pendidikan merupakan perwujudan nyata dari upaya sungguh-sungguh pemerintah untuk meningkatkan kualitas masyarakat Indonesia yang telah mengalami keterbelakangan disebabkan penjajahan.

Data pada tahun 1951 menunjukkan bahwa terdapat 10.962.000 murid yang bersekolah di Sekolah Rakyat (SR), dan dari jumlah tersebut yang dapat ditampung adalah 5.040.850. Untuk dapat menampung seluruh murid usia SR tersebut dibutuhkan tambahan 138.240 guru. Langkah pintas pemerintah yang ditempuh untuk mengatasi kekurangan guru ini didirikanlah KPKPKB (Kursus Pengajar untuk Kursus Pengantar ke Kewajiban Belajar). Pada tahun 1953 semua KPKPKB dinyatakan sebagai SGB sehingga pada tahun tersebut terdapat 500 SGB di seluruh Indonesia. Untuk memenenuhi kebutuhan guru sekolah lanjutan pada tahun 1954/1955 didirikan PGSLP (Pendidikan Guru Sekolah Lanjutan Pertama) sebanyak 26 buah. Pada 1954 dibuka Perguruan Tinggi Pendidikan Guru yang kemudian pada 1963 menjadi Institut Keguruan dan Ilmu Pendidikan (IKIP). ${ }^{39}$

Berkenaan dengan pendidikan agama diatur secara khusus dalam UU No, 4 Tahun 1950 pada bab XII Pasal 20, yaitu bahwa di sekolahsekolah negeri diadakan pelajaran agama, orang tua murid menetapkan apakah anaknya akan mengikuti pelajaran tersebut atau tidak. Cara penyelenggaraan pendidikan agama di sekolah negeri diatur dalam peraturan yang ditetapkan oleh Menteri Pendidikan Pengajaran dan Kebudayaan, bersama-sama dengan Menteri Agama. Perkembangan pendidikan Islam pada masa Orde Lama sangat terkait pula dengan peran Departemen Agama yang mulai resmi

\footnotetext{
38 Ary H. Gunawan, Kebijakan-Kebijakan Pendidikan di Indonesia, h. 46.

39 Ary H. Gunawan, Kebijakan-Kebijakan Pendidikan di Indonesia, h. 48.
} 
berdiri pada 3 Januari 1946. Departemen Agama sebagai suatu lembaga pada masa itu, secara intensif memperjuangkan politik pendidikan Islam di Indonesia. Pendidikan Islam pada masa itu ditangani oleh suatu bagian khusus yang mengurus masalah pendidikan agama, yaitu Bagian Pendidikan Agama.

Kebijakan pemerintah yang memasukkan pendidikan agama sebagai materi belajar di sekolah tentunya berbeda dengan keadaan pada masa-masa pendudukan Belanda. Pada masa pendudukan Belanda di samping pendidikan bersifat sekuler, pendidikan yang diselenggarakan pemerintah Belanda juga diskriminatif, dalam arti persekolahan didasarkan pada strata kelas masyarakat. Ada sekolah untuk anak orang Eropa, untuk anak orang Asing Timur (Cina dan Arab), untuk anak orang bangsawan, dan untuk anak orang kebanyakan. Pendidikan yang dilangsungkan juga diorientasikan kepada kebudayaan Barat dengan asumsi budaya Barat lebih tinggi dan beradab daripada budaya setempat. ${ }^{40}$

Sampai di sini dapat diketahui bahwa terjadi perubahan dalam memberikan perhatian terhadap muatan pendidikan agama di sekolah. Pada jaman pendudukan Belanda dan Jepang pendidikan agama tidak mendapatkan tempat di sekolah-sekolah pemerintah. Kemudian pada masa awal kemerdekaan pendidikan agama mulai dimasukkan dalam sekolah yang diselenggarakan pemerintah, walaupun harus atas persetujuan orang tua siswa. Hal ini tidak lepas dari konteks Indonesia yang senantiasa dinamis, sehingga dapat disebutkan bahwa dinamisasi yang terjadi di ranah religio-sosial politik ekonomi menimbulkan terjadinya dinamisasi arah dan tujuan pendidikan. Hal ini senada dengan yang disebutkan HAR Tilaar bahwa pendidikan dan politik memiliki keterkaitan, namun pendidikan tidak dapat menggantikan fungsi politik. Akan

\footnotetext{
${ }^{40}$ Ailsa Zainu'ddin, Education in the Netherlands East Indies and the Republic of Indonesia' dalam Selleck, R. J. W, Studies in Education (Melbourne: Melbourne University Press, 1970). p. 19.
}

tetapi tanpa pendidikan tujuan-tujuan politik sulit terlaksana. Oleh karena itu fungsi dan peranan pendidikan dalam kehidupan suatu bangsa tidak dapat dipisahkan dari kehidupan politik, ekonomi, hukum, dan kebudayaan pada umumnya dalam suatu bangsa. ${ }^{41}$

Dinamisasi yang terjadi berkaitan dengan kebijakan pendidikan sebagaimana disebut di atas tergambar jelas dimulai masa-masa awal kemerdekaan muncul kalangan para pendidik nasional yang kemudian tergabung dalam panitia kecil yang menjadi bagian dari BPUPKI dan diketuai oleh Ki Hajar Dewantara memutuskan bahwa pendidikan agama diberikan di sekolahsekolah pemerintah. Mulai saat itu arah pendidikan nasional mulai meninggalkan arah pendidikan yang dilangsungkan oleh Belanda sebelumnya. Sifat konvensional pendidikan nasional ini tercermin dalam Sepuluh Dasar Pendidikan Nasional yang diumumkan oleh Menteri PP\&K Mr. Suwandi, di 1947 di mana dasar pendidikan nasional yang pertama adalah pengembangan rasa berbakti kepada Tuhan. ${ }^{42}$

Pada tahun 1950 diadakan revisi atas tujuan pendidikan nasional. Di dalam Undang-Undang nomor 4 tahun 1950 tentang dasar-dasar pendidikan dan pengajaran di sekolah, tujuan pendidikan nasional itu dirumuskan menjadi membentuk manusia susila yang cakap dan warga negara yang demokratis serta bertanggungjawab atas kesejahteraan masyarakat

\footnotetext{
${ }^{41}$ H.A.R. Tilaar, Paradigma Baru Pendidikan Nasional, (Jakarta: Rineka Cipta, 2002). h. 2.

42 Arif Furqon, "Pergeseran Sifat Konvensionalitas Pendidikan Nasional Indonesia”, dalam Ulul Albab: Jurnal Studi Islam, Sains, dan Teknologi. (Malang: Universitas Islam Negeri Malang, 2004). Vol. 5 Nomor 1, 74. Istilah konfessional sebenarnya berasal dari istilah dalam pendidikan agama yang mengacu pada pendidikan agama yang bertujuan untuk menanamkan rasa keimanan kepada suatu agama tertentu pada diri siswa, kebalikan dari pendidikan semacam ini adalah pendidikan agama non-konfessional (non-confessional religious education), yaitu pendidikan agama yang hanya bertujuan untuk membantu siswa menyadari akan adanya berbagai kepercayaan yang diyakini oleh berbagai kelompok dalam masyarakatnya. Basil Moore, The Nature of Religious Education, dalam Graham M Rossiter Religious Education in Australian Schools. (Canberra: Curriculum Development Center, 1981). p. 160.
} 
dan tanah air ${ }^{43}$. Pengertian manusia susila dapat ditafsirkan sebagai manusia berakhlak menurut ajaran agama, sehingga memerlukan pendidikan agama. Tetapi bisa juga istilah tersebut ditafsirkan sebagai yang tidak memerlukan pendidikan agama, karena manusia bermoral tidak selalu harus beragama. Rumusan ini juga selaras dengan tidak wajibnya muatan pendidikan agama di sekolah negara. Dengan rumusan ini maka baik sekolah yang menyelenggarakan pendidikan agama atau pun tidak sama-sama dapat mewujudkan tujuan pendidikan secara penuh.

Setelah terjadinya gerakan pemberontakan tanggal 30 September oleh Partai Komunis Indonesia (G-30-S/PKI) pemerintah mengubah status pendidikan agama di sekolah negeri menjadi wajib. Namun perubahan status ini tidak diikuti perubahan rumusan tujuan pendidikan. Rumusan tujuan pendidikan nasional pada tahun 1966 sebagaimana Ketetapan MPRS no. XXVII/1966 adalah pendidikan bermaksud untuk membentuk manusia Pancasilais Sejati berdasarkan ketentuan yang dikehendaki oleh UUD 1945. Rumusan tujuan pendidikan tersebut masih bersifat umum, karena istilah manusia pancasilais sejati merupakan istilah yang multi tafsir dan mengesankan sebagai reaksi atas peristiwa G30S/PKI.

Pada tahun 1973 dalam Tap MPR tahun 1973 tentang Garis Besar Haluan Negara (GBHN), tujuan pendidikan nasional dirumuskan sebagai berikut: pendidikan diarahkan untuk membentuk manusia pembangun yang sehat jasmani dan rohaninya, dapat memiliki pengetahuan dan keterampilan yang bertanggung jawab. ${ }^{44}$ Disebutkannya

\footnotetext{
43 Undang-Undang Nomor 4/1950 tentang Dasar Pendidikan dan Pengajaran.

${ }^{44}$ H.M. Kasiram, Mengenal Sistem Pendidikan Nasional Indonesia Menurut UUSPN no.2 tahun 1989, dalam Bahan Penataran P4 Pola Dukung 100 jam. (Malang: IAIN Sunan Ampel, Fakultas Tarbiyah, 1993) h. 98.
}

kesehatan rohani menempatkan pendidikan agama pada posisi penting (sebagai sarana untuk mencapai tujuan itu), walaupun masih dapat diperdebatkan juga apakah orang yang sehat rohaninya harus orang yang taat agamanya. Rumusan tujuan pendidikan nasional tahun 1973 ini tidak secara eksplisit menunjukan sifat konvensional pendidikan agama di sekolah.

Pada tahun 1978 terjadi perubahan rumusan tujuan pendidikan nasional. Di dalam Tap MPR tahun 1978 tentang GBHN, rumusan pendidikan nasional adalah pendidikan nasional berdasarkan atas Pancasila dan bertujuan untuk meningkatkan ketakwaan terhadap Tuhan Yang Maha Esa, kecerdasan, keterampilan, mempertinggi budi pekerti, memperkuat kepribadian dan mempertebal semangat kebangsaan agar dapat menumbuhkan manusia pembangun yang dapat membangun dirinya sendiri dan bersama-sama bertanggungjawab atas pembangunan bangsa.

Pada 1988 rumusan tujuan pendidikan nasional sebagaimana tersebut di atas mengalami revisi. Di dalam GBHN yang ditetapkan di 1988 aspek kerohanian manusia ideal Indonesia ditambah dengan unsur beriman sehingga rumusannya menjadi Pendidikan nasional berdasarkan Pancasila bertujuan untuk meningkatkan kualitas manusia yang beriman dan bertakwa kepada Tuhan Yang Maha Esa, berbudi pekerti luhur, berkepribadian, berdisiplin, bekerja keras, bertanggung jawab, mandiri, cerdas dan terampil, sehat jasmani dan rohani. Pada saat itu, pendidikan agama hanya diwajibkan di sekolah negara, ada pun di sekolah swasta sifatnya hanya suka rela. Mengamati dinamika yang terjadi di dalam dunia pendidikan Indonesia periode 1945 sampai 1988, menjadi penting untuk dicatat bahwa pendidikan agama mengalami pergeseran. Secara perlahan, dimulai dari rumusan tujuan pendidikan posisi pendidikan agama semakin kuat, dan semakin kuat pada periode berikutnya. 


\section{Undang-Undang Nomor 2 Tahun 1989 tentang Sistem Pendidikan Nasional}

Salah satu karya tulis yang secara khusus mengkaji tentang kebijakan lahirnya UU no. 2 tahun 1989 adalah yang ditulis oleh Muhammad Sirozi. Secara khusus karya ini mengkaji tentang peran tokoh-tokoh Islam dalam penyusunan UU no. 2 tahun 1989. Disebutkan oleh Sirozi bahwa para pemimpin muslim sangat antusias dalam ikut serta menyuarakan aspirasinya selama proses penyusunan UU ini. Semua saluran untuk menyuarakan aspirasi kepada pemerintah dilakukan oleh para pemimpin muslim. Hal demikian dilakukan dikarenakan para pemimpin muslim dan umat muslim Indonesia berkepentigan untuk menjadikan pendidikan agama sebagai pendidikan yang wajib diajarkan di sekolah. Isu krusial mengenai pedidikan agama adalah yang paling diperhatikan. ${ }^{45}$

Sirozi menyimpulkan bahwa keterlibatan para tokoh muslim dalam perdebatan RUSPN tahun 1989 menyangkut niat untuk mengesahkan dan meniadakan pendidikan tertentu berdasar persepsi khusus tentang hak agama dan ideologi nasional. Mereka ingin mendesak pemerintah Indonesia dan lembaga legislatifnya untuk menganut sistem pendidikan nasional yang beragama. Mereka para tokoh muslim berdalih bahwa terlibat dalam pendidikan agama di sekolah merupakan salah satu hak agama semua anak Indonesia. mereka juga berdalih bahwa memberikan hak agama demikian relevan dengan asas pertama ideologi nasional Pancasila. ${ }^{46}$ Meskipun orientasi para pemimpin muslim tetap konsisten, pilihan strategi pengaruh mereka cenderung dimodifikasi sesuai dengan situasi lingkungan dan organisasi. berjuangan para pemimpin muslim dalam

${ }^{45}$ Di dalam karyanya Sirozi mengakui bawa terdapat kelemahan dalam penggunaan istilah Pemimpin Muslim. Sirozi memilih 12 tokoh pemimpin muslim yang ia jadikan sebagai sumber iformasi. Muhammad Sirozi, Politik Kebijakan Pendidikan di Indoensia, h. 120.

46 Muhammad Sirozi, Politik Kebijakan Pendidikan di Indoensia, h. 287. menyampaikan aspirasinya lebih banyak disuarakan melalui forum-forum tak resmi, dan hal ini dikarenakan mereka, percaya bahwa dalam politik Orde Baru negosiasi tak resmi lebih efektif daripada yang resmi.

Di antara faktor lingkungan yang mempengaruhi pilihan startegi pemimpin muslim dalam menyampaikan aspirasinya adalah peraturan yang ada, struktur pranata kebijakan, dan pola hubungan mereka dengan pemeritahan Orde Baru. Selain itu, mereka juga bertindak menurut pertimbangan strategis mereka sendiri. Misalnya saja sebelum mengadakan kontak resmi dengan para pembuat kebijakan, para pemimpin muslim secara intensif mengadakan kontak tak resmi dengan tokoh-tokoh penting dalam badan birokrasi yang terkait dan parlemen. Karena membuat kontak tidak resmi tidak ada dalam batas peraturan keputusan yang ada, dapat dikatakan bahwa inisiatif pemimpin muslim dalam membuat kontak ini adalah tindakan pilihan strategis. ${ }^{47}$

Selain itu, faktor yang paling penting dalam pilihan strategi para pemimpin muslim adalah kredibilitas para pelobi mereka dan kesesuaian kegiatan kelompok mereka. Sirozi dalam hal ini menyebutkan bahwa kebanyakan dari para pemimpin muslim yang aktif dalam lobi adalah politisi dan pendidik yang kredibel dan berpengalaman, yang banyak tahu tentang budaya dan kerumitan sistem politk Indonesia dan masalah yang ada dalam sistem pendidikan nasional Indonesia. Pada akhirnya mereka dapat menyampaikan usulannya dan sebagian besar usulan itu diterima oleh pembuat kebijakan. Penerimaan oleh pembuat kebijakan dihasilkan setelah para pemimpin muslim melakukan lobi sangat intensif. ${ }^{48}$

Di dalam Undang-Undang No. 2/1989 menyebutkan bahwa pendidikan agama wajib diberikan kepada setiap jenis, jalur, dan jenjang

\footnotetext{
47 Muhammad Sirozi, Politik Kebijakan Pendidikan di Indoensia, h. 284

48 Muhammad Sirozi, Politik Kebijakan Pendidikan di Indoensia, h. 285.
} 
pendidikan. ${ }^{49}$ Dengan adanya ketentuan ini, maka pendidikan agama wajib diajarkan di semua jenis dan jenjang sekolah, baik sekolah milik negara maupun sekolah swasta. Selain dari itu, dalam Undang-Undang ini disebutkan bahwa pendidikan adalah usaha sadar untuk menyiapkan peserta didik melalui kegiatan bimbingan, pengajaran, dan/atau latihan bagi peranannya di masa yang akan datang. ${ }^{50}$

Pasal 3 Undang-Undang ini juga menegaskan bahwa pendidikan nasional berfungsi untuk mengembangkan kemampuan serta meningkatkan mutu kehidupan dan martabat manusia Indonesia dalam rangka upaya mewujudkan tujuan nasional. Sedangkan pada Pasal 4 disebutkan bahwa Pendidikan Nasional bertujuan mencerdaskan kehidupan bangsa dan mengembangkan manusia Indonesia seutuhnya, yaitu manusia yang beriman dan bertaqwa terhadap Tuhan Yang Maha Esa dan berbudi pekerti luhur, memiliki pengetahuan dan keterampilan, kesehatan jasmani dan rohani, kepribadian yang mantap dan mandiri serta rasa tanggung jawab kemasyarakatan dan kebangsaan. ${ }^{51}$

Lahirnya UU No. 2 Tahun 1989 tentang Sistem Pendidikan Nasional yang diundangkan dan berlaku sejak tanggal 27 Maret 1989, memberikan perbedaan yang sangat mendasar bagi pendidikan agama. Pendidikan agama tidak lagi diberlakukan berbeda untuk sekolah negeri dan swasta, dan sebagai konsekuensinya diberlakukan Peraturan Pemerintah sebagai bentuk operasional undang-undang tersebut, yaitu PP 27/1990 tentang Pendidikan Pra Sekolah, PP 28/1990 tentang Pendidikan Dasar, PP. 29/1990 tentang Pendidikan Menengah, PP. No. 30/1990 tentang Pedidikan Tinggi (disempurkan dengan PP.22/1999). Semua itu mengatur pelaksanaan pendidikan agama di

\footnotetext{
${ }^{49}$ Pasal 39 ayat 2 Undang-undang no 2 tahun 1989.

${ }^{50}$ Bab I tentang Ketentuan Umum, Pasal 1 ayat 1 UU Nomor 2 Tahun 1989 tentang Sisdiknas.

${ }^{51}$ Pasal 3 dan Pasal 4 UU Nomor 2 Tahun 1989.
}

lembaga pendidikan umum. UU dan peraturan pemerintah tersebut telah memberi dampak positif bagi lembaga-lembaga pendidikan Islam. Sejak diberlakukan UU No. 2 Tahun 1989 tesebut lembaga-lembaga pendidikan Islam menjadi bagian integral (subsistem) dari sistem pendidikan nasional. Sehingga dengan demikian, kebijakan dasar pendidikan agama pada lembagalembaga pendidikan Islam adalah sebangun dengan kebijakan dasar pendidikan agama pada lembaga-lembaga pendidikan nasional secara keseluruhan.

UU ini juga telah memuat ketentuan tentang hak setiap siswa untuk memperoleh pendidikan agama sesuai dengan agama yang dianutnya. Namun, SD, SLTP, SMU, SMK dan SLB yang berciri khas berdasarkan agama tertentu tidak diwajibkan menyelenggarakan pendidikan agama lain dari agama yang menjadi ciri khasnya. Inilah ketentuan yang pada masa setelahnya menimbulkan polemik dan kritik dari sejumlah kalangan, di mana para siswa dikhawatirkan akan pindah agama (berdasarkan agama Yayasan/Sekolah), karena mengalami pendidikan agama yang tidak sesuai dengan agama yang dianutnya. Kritik itu semakin kencang, dengan keluarnya Peraturan Pemerintah, No. 29/1990, yang secara eksplisit menyatakan bahwa sekolah-sekolah menengah dengan warna agama tertentu tidak diharuskan memberikan pelajaran agama yang berbeda dengan agama yang dianutnya.

UU No. 2 tahun 1989 itu dan peraturan pemerintah tersebut dinilai oleh sebagian kalangan sebagai UU yang tidak memberikan ruang dialog keagamaan di kalangan siswa. Ia juga memberikan peran tidak langsung kepada sekolah untuk mengelompokkan siswa berdasarkan agama. Dalam UU No 2 Tahun 1989 disebutkan bahwa tujuan pendidikan nasional adalah Pendidikan Nasional bertujuan mencerdaskan kehidupan bangsa dan mengembangkan manusia Indonesia seutuhnya, yaitu manusia yang beriman dan bertaqwa 
terhadap Tuhan Yang Maha Esa dan berbudi pekerti luhur, memiliki pengetahuan dan keterampilan, kesehatan jasmani dan rohani, kepribadian yang mantap dan mandiri serta rasa tanggung jawab kemasyarakatan dan kebangsaan. ${ }^{52}$

Bagi Malik Fadjar, Undang-Undang Sistem Pendidikan Nasional tahun 1989 merupakan murni sebagai aspirasi dari era kemerdekaan, walaupun praktiknya pendidikan yang berlangsung juga belum dapat terbebaskan dari produk masa lalu. Dalam hal ini terutama berkaitan dengan pengakuan dan penghargaan, yang tolok ukurnya lebih banyak tergantung pada political will pemerintah, yang selalu menjadi acuan pokok. Oleh sebab itu, menurut Fadjar semua institusi pendidikan formal baik berupa sekolah, madrasah, perguruan tinggi maupun podok pesantren baik sistem maupun penyelenggaraannya sangat terkait oleh sistem yang dibakukan oleh pemerintah. Walaupun diakuinya hal itu sering mengandung konsekuensi metodologis-pedagogis maupun dikotomi epistemologis-teoritik yang kurang dikehendaki. ${ }^{53}$

Dibandingkan dengan UU tentang pendidikan yang lahir sebelumnya, UU no. 2 tahun 1989 jauh lebih maju dalam menentukan posisi pendidikan agama bagi masyarakat Indonesia. Jika di dalam Undang-Undang Nomor 4 Tahun 1950 jo. Undang-Undang Nomor 12 Tahun 1954 Tentang Pendidikan dan Pengajaran menentukan bahwa pendidikan agama diberikan kepada murid di sekolah umum atas seijin orang tua murid, maka di dalam UU no 2 tahun 1989 ditentukan bahwa pendidikan agama wajib diberikan kepada semua murid di semua jenjang dan jenis pendidikan. Perubahan yang terjadi tidak lepas dari konteks yang melingkupinya.

\footnotetext{
${ }^{52}$ Undang-Undang Republik Indonesia Nomor 2 Tahun 1989 Tentang Sistem Pendidikan Nasional.

${ }^{53}$ A. Malik Fadjar, Visi Pembaruan Pendidian Islam (Jakarta: Lembaga Pengembangan Pendidikan dan Penyususnan Naskah Indonesia, 1998), h. 21-22.
}

\section{Undang-Undang Nomor 20 Tahun 2003 tentang Sistem Pendidikan Nasional}

Salah satu masalah utama yang menjadi kontroversi dalam proses pengesahan UU Sisdiknas No 20 tahun 2003 adalah masalah status pendidikan agama di sekolah umum. Pendapat masyarakat dan fraksi di DPR secara sederhana dapat dikelompokan ke dalam dua kelompok. Kelompok pertama adalah yang menginginkan pendidikan agama menjadi pelajaran wajib di sekolah umum dan kelompok kedua adalah yang menginginkan pendidikan agama tidak menjadi pelajaran wajib di sekolah umum. Menurut Arif Furqon kontroversi ini merupakan pengulangan dari kontroversi atas persoalan yang sama ketika DPR membuat UU Sisdiknas nomor 2 tahun 1989. Kedudukan pendidikan agama yang demikian mantap di dalam UU Sisdiknas ini tampaknya menimbulkan persoalan di kalangan para penyelenggara pendidikan non-pemerintah. Persoalan yang muncul seperti apakah sekolah yang didirikan oleh yayasan yang berlandaskan keagamaan juga harus memberikan pendidikan agama bagi siswa yang agamanya berbeda dari agama yang dianut oleh yayasan pendidikan tersebut?. Dalam hal ini, Furqon mencontohkan apakah SMP NU harus memberikan pelajaran agama Kristen bagi siswanya yang beragama Kristen atau apakah sekolah Katolik harus memberikan pendidikan agama Islam bagi siswanya yang beragama Islam. Rupanya misal yang kedua inilah yang lebih mengganggu penyelenggara pendidikan swasta dari pada misal yang pertama. Hal ini dikarenakan siswa muslim yang berada di sekolah binaan yayasan keagamaan non-Islam jauh lebih banyak jumlahnya dari pada siswa non-Muslim yang belajar di sekolah Islam. Hal tersebut menjadi janggal mengingat dalam sejarah pendidikan di Indonesia, lembaga pendidikan telah digunakan sebagai media dakwah. Pondok pesantren adalah contoh yang nyata dari kecenderungan ini. Pondok pesantren biasanya didirikan oleh ulama 
atau kyai dengan niat dakwah. Demikian halnya juga dengan agama Kristen. Sejak zaman Belanda, misi dan zending telah menggunakan lembaga pendidikan sebagai media mengembangkan agama mereka. Keharusan untuk memberikan pendidikan agama lain di lembaga pendidikan yang tujuan asalnya untuk dakwah agamanya akan terasa janggal. ${ }^{54} \mathrm{Hal}$ inilah rupanya yang mendasari keberatan para penyelenggara pendidikan non-pemeritah menyangkut pendidikan agama dalam UU Sisdiknas ini.

Di antara argumen dari pihak yang keberatan dari ketentuan ini adalah bahwa sebaiknya pemerintah tidak perlu ikut campur mengatur masalah pendidikan agama di sekolah swasta itu. Menurut mereka sebaiknya masalah itu diserahkan saja kepada masyarakat pengguna jasa pendidikan untuk menentukan sikapnya. Apalagi masyarakat sudah tahu bahwa di suatu lembaga pendidikan yang dikelola oleh yayasan keagamaan tertentu hanya akan memberikan pendidikan agama yang dianut oleh yayasan tersebut. Jika masyarakat tidak ingin mendapatkan pendidikan agama yang diberikan di suatu sekolah maka sebaiknya tidak memasukkan anaknya ke sekolah tersebut, dan dapat memilih sekolah negeri atau sekolah swasta lain yang memberikan pendidikan agama sesuai dengan agama anaknya. Menurut Arif Furqon pandangan ini memang masuk akal apalagi sekolah tidak memaksa masyarakat memasukkan anaknya ke sekolah yang dikelola yayasan keagamaan tertentu dan pasti orang tua sebelumnya sudah mengetahui bahwa anaknya tidak akan menerima pendidikan agama sesuai dengan agama si anak. Namun bagi Furqon pendapat ini memiliki beberapa kelemahan bila dilihat dari dasar, fungsi, dan tujuan pendidikan nasional di Indonesia. Usulan tersebut menurut

\footnotetext{
${ }^{54}$ Arif Furqon, Pergeseran Sifat Konfessionalitas Pendidikan Nasional Indonesia, dalam Ulul Albab: jurnal studi Islam, sains, dan teknologi 5(1), (Malang: Universitas Islam Negeri Malang, 2004), h. 67-68.
}

Furqon berawal dari asumsi bahwa pendidikan di Indonesia bersifat sekuler yang menempatkan pendidikan agama pada posisi tidak penting, dan akan popular di negeri sekuler seperti kebanyakan negara Barat. ${ }^{55}$

Di dalam konteks Negara Pancasila seperti Indonesia, tampaknya pendapat sebagaimana tersebut di atas akan sulit diterima. Selain itu, telah ditegaskan bahwa tujuan pendidikan nasional Indonesia adalah untuk mencerdaskan kehidupan bangsa dan mengembangkan manusia Indonesia seutuhnya, yaitu manusia yang beriman dan bertakwa kepada Tuhan Yang Maha Esa dan berbudi pekerti luhur, memiliki pengetahuan dan keterampilan, kesehatan jasmani dan rohani, kepribadian yang mantap dan mandiri serta rasa tanggung jawab kemasyarakatan dan kebangsaan. Makna beriman dan bertakwa selalu diartikan menurut agama masing-masing, sehingga setiap siswa harus mendapatkan pendidikan agama menurut agama siswa. $^{56}$

Pasal yang menjadi perdebatan yang menjadi sangat menentukan keberhasilan pendidikan agama adalah pasal 12 yang menyebutkan bahwa pendidikan agama adalah hak setiap peserta didik. "Setiap peserta didik pada setiap satuan pendidikan berhak mendapatkan pendidikan agama sesuai dengan agama yang dianutnya dan diajarkan oleh pendidik yang seagama. ${ }^{157}$ Dalam bagian penjelasan diterangkan pula bahwa pendidik atau guru agama yang seagama dengan peserta didik difasilitasi atau disediakan oleh

\footnotetext{
${ }^{55}$ Arif Furqon, Pergeseran Sifat Konfessionalitas Pendidikan Nasional Indonesia, h. 68-69.

${ }^{56}$ Arif Furqon, Pergeseran Sifat Konfessionalitas Pendidikan Nasional Indonesia, h. 70. Penjelasan atas pasal 37 ayat 1 ini ditegaskan, 'pendidikan agama dimaksudkan untuk membentuk peserta didik menjadi manusia yang beriman dan bertakwa kepada Tuhan Yang Maha Esa serta berakhlak mulia'. Pelaksanaan pendidikan agama di sekolah umum, juga diatur dalam undang-undang baik yang berkaitan dengan sarana dan prasarana pendidikan, biaya pendidikan, tenaga pengajar, kurikulum dan komponen pendidikan lainnya.

${ }^{57}$ Pasal 12 ayat a UU RI Nomor 20 Tahun 2003 tentang Sistem Pendidikan Nasional.
} 
pemerintah atau pemerintah daerah sesuai dengan kebutuhan satuan pendidikan. ${ }^{58}$ UU ini juga sekaligus menutup bagian dari UU No. 2/1989 dan Peraturan Pemerintah, No. 29/1990, tentang tidak wajibnya sekolah dengan latar belakang agama tertentu (misalnya Islam) mengajarkan pendidikan agama yang dianut siswa (misalnya pelajaran agama Katolik untuk siswa yang beragama Katolik). UU Sistem Pendidikan Nasional No. 20 tahun 2003 inilah yang menjadi pijakan hukum dan konstitusional bagi penyelenggaraan pendidikan agama di sekolah-sekolah, baik negeri maupun swasta. Di dalamnya disebutkan bahwa 'kurikulum pendidikan dasar dan menengah wajib memuat pendidikan agama, pendidikan kewarganegaraan, bahasa, matematika, ilmu pengetahuan sosial, seni dan budaya, pendidikan jasmani dan olahraga, keterampilan/kejuruan dan muatan lokal ${ }^{59}$.

Inti dari UU Nomor 20 Tahun 2003 adalah bahwa pelaksanaan pendidikan yang dilangsungkan di Republik ini harus mengarah pada perwujudan manusia yang beriman dan bertakwa kepada Tuhan Yang Maha Esa. Pengertian manusia yang beriman dan bertakwa diartikan menurut agama masing-masing, dan ini konsisten dengan diberikannya pendidikan agama yang bersifat konfessional menurut agama siswanya secara wajib. Dalam istilah pendidikan, tujuan pendidikan yang dirumuskan seperti tersebut dapat dikatakan bersifat konfessional, artinya tujuan pemberian pendidikan agama kepada siswa adalah untuk membina siswa agar menjadi penganut agama yang taat. Pergeseran yang terjadi bermuara pada usaha terwujudnya manusia Indonesia yang memiliki keimanan dan ketakwaan kepada Tuhan Yang Maha Esa, dengan ciri-ciri berbudi pekerti luhur, memiliki pengetahuan dan keterampilan, kesehatan jasmani dan rohani, kepribadian yang mantap

\footnotetext{
${ }^{58}$ Pasal 41 ayat 3 UU RI Nomor 20 Tahun 2003 tentang Sistem Pendidikan Nasional.

${ }^{59}$ Pada pasal 37 ayat 1 UU RI Nomor 20 Tahun 2003 tentang Sistem Pendidikan Nasional.
}

dan mandiri serta rasa tanggung jawab kemasyarakatan dan kebangsaan.

Pendidikan agama pada saat sekarang mendapat tempat yang mantap dalam sistem pendidikan nasional. Ia telah menjadi materi yang harus dimasukkan ke dalam semua jenis dan semua jenjang pendidikan. Hal ini adalah sebagaimana yang diamanatkan oleh UndangUndang Sistem Pendidikan Nasional (UU Sisdiknas) No. 3 tahun 2003. Produk UndangUndang yang berkenaan dengan pendidikan sejak 1945 sampai yang paling terakhir tahun 2003 mengindikasikan secara kuat bahwa terjadi pergeseran sifat pendidikan nasional, dari yang semula sekuler menjadi bersifat lebih menerima muatan keagamaan dalam pendidikan.

Paparan di atas menunjukan adanya pergeseran komitmen para pembuat kebijakan dalam mengupayakan terwujudnya masyarakat Indonesia yang religius dengan memiliki pemahaman yang baik terhadap agama yang dipeluknya. Hal ini merupakan hasil dari perjuangan panjang dari segenap umat muslim Indonesia, yang dari dulu hingga sekarang menghendaki adanya pengakuan yang adil dari pemerintah atas semua lembaga pendidikan yang ada dan berkembang di bumi Indonesia. Sudah menjadi keharusan negara untuk memberikan penghormatan yang pantas atas peran serta seluruh lembaga pendidikan yang ada. Pada dasarnya mereka semua sedang bersama-sama secara real membangun negara bangsa Indonesia, lewat jalur pendidikan. Hal ini sesuai dengan yang dinyatakan oleh Malik Fadjar, bahwa kita jangan melihat kecilnya suatu surau, misalnya, yang berada di jauh dari hiruk pikuk perkotaan, akan tetapi jika dilihat secara lebih mendalam maka akan dirasakan sumbangsih dari keberadaan surau tersebut dalam upaya ikut serta membangun bangsa, yang bersendikan Ketuhanan Yang Maha Esa. 
Dinamika Politik Pendidikan Agama di Indonesia ....(Muhammad Bisyri) | 271

\section{Implementasi Pendidikan Agama di Sekolah Perspektif UU Nomor 20 Tahun 2013}

Sebagaimana disebutkan di atas, bahwa ketentuan diberikannya pendidikan agama yang sesuai dengan agama siswa dan diajarkan oleh guru yang seagama bagi pihak tertentu dirasa berat. Keberatan seperti ini secara nyata ditemui oleh penulis tatkala bertanya kepada salah satu pimpinan suatu yayasan bercirikan agama tertentu yang mengelola lembaga pendidikan. Menurutnya, bahwa yayasannya didirikan adalah dengan tujuan untuk mendidik generasi penerus pemimpin agama yang tangguh. Walaupun yayasan tersebut membuka kemungkinan untuk menerima siswa yang berlainan agama dengan yayasan, namun yayasan berkeberatan kalau harus memberikan pendidikan agama yang dianut oleh siswa tersebut. ${ }^{60}$ Adapun contoh dari sekolah yang memberikan bimbingan pendidikan agama kepada siswanya sesuai dengan agamanya masng-masing adalah Sekolah Madania yang beralamat di Parung Bogor Jawa Barat, dan Sekolah High Scope Indonesia yang beralamat di Bintaro Tangerang Selatan Banten.

Sekolah Madania Parung Bogor dengan sangat terang memberikan bimbingan pelajaran agama kepada semua siswanya sesuai dengan agama para siswa masing-masing. $\mathrm{Hal}$ ini dasarkan atas pandangan bahwa keragaman agama merupakan kenyataan global. Sekolah Madania berpandangan bahwa sekolah selain mendidik siswa untuk berketerampilan dengan baik, berpengetahuan yang manfaat, siswa juga dididik untuk mampu bermoral tinggi dengan tuntunan ajaran agama yang diyakininya. Disebutkan bahwa pendidikan agama tidak diajarkan untuk menghafal pesan-pesan agama semata namun lebih dari itu siswa dituntut untuk mampu mengamalkan ajaran agamanya

\footnotetext{
${ }^{60}$ Informasi ini penulis gali dari Ketua sebuah yayasan yang membawahi lembaga pendidikan dari tingkat TK sampai SLTA.
}

dalam kehidupan kesehariannya. Sekolah Madania yang di dalamnya terdapat siswa dari beragam latar belakang agama, memberikan bimbingan pendidikan agama sesuai dengan agama siswanya, termasuk di antaranya Islam, Kristen, Katolik, Budha, Hindu. ${ }^{61}$

Selain sekolah Madania, contoh lain dari sekolah yang memberikan pendidikan agama sesuai dengan agama siswanya adalah Sekolah High Scope Indonesia yang berlokasi di Bintaro Tangerang Selatan Banten. Berdasar informasi yang didapat dari siswa SLTP sekolah High Scope Bintaro, di setiap jam pelajaran agama siswa dikelompokkan sesuai dengan agamanya masing-masing dan mendapatkan pelajaran agama sesuai dengan agama siswa yang diajarkan oleh guru-guru yang seagama. Seusai pelajaran agama siswa dikelaskan sesuai dengan kelas sebelumnya. ${ }^{62}$

Sepertinya sekolah-sekolah baik negeri maupun swasta, baik yang berada di bawah yayasan keagamaan maupun sekolah yang berada di bawah yayasan non-Keagamaan memerlukan kekuatan lebih agar dapat mengimplementasikan amanat UU Sisdiknas nomor 20 tahun 2003. Kekuatan yang dimaksud antara lain kekuatan tekad untuk mengamalkan UU, dan selain dari itu adalah kekuatan ketersediaan fasilitas dan pembiayaan untuk memenuhi segala kebutuhannya. Tidak kalah penting adalah

\footnotetext{
${ }^{61}$ Sekolah Madania Bogor didirikan oleh Nurcholis Madjid, Ahmad Fuadi, dan Komaruddin Hidayat. Jika melihat ketiga pendiri sekolah ini, dapat dimaklumi jika sekolah Madania dari awal telah inklusif dengan menerima siswa dari agama yang beragam, dan memberikan pelajaran agama sesuai dengan agama siswa. Hal ini karena Nurcholis Madjid dan Komaruddin Hidayat adalah aktor penting dalam diskursus pemikiran pluralisme agama di Indonesia. Jika yang pertama adalah tokoh utama, maka tokoh kedua adalah tokoh penerus utama yang mewarnai pemikiran pluralism agama di Indonesia. Inklusivitas para pendiri sekolah ini sangat wajar kemudian terrefleksi dalam sekolah yang didirikannya, dan praktik seperti inilah yang diamanatkan oleh UU Sisdiknas nomor 20 tahun 2003.

${ }^{62}$ Walaupun sekilas, informasi yang penulis peroleh dari siswa sekolah ini oleh penulis dianggap penting. Sekolah ini menerima siswa dari beragam latar belakang agama dan memberikan pendidikan agama sesuai dengan agama siswa masing-masing.
} 
kekuatan pemerintah untuk memberikan pendampingan, dan pengawasan terhadap seluruh sekolah agar dapat mengamalkan amanat UU secara istikamah.

\section{Penutup}

Terdapat kaitan yang sangat kuat antara politik dan pendidikan di setiap Negara, termasuk Indonesia. Hal memiliki arti bahwa setiap kebijakan tentang pendidikan di setiap Negara lahir dari pemikiran dan perubahan yang panjang. Konteks sosial, politik, ekonomi, agama, dan lainnya sangat mempengaruhi setiap produk undang-undang. Jika dilihat dari produk perundang-undangan yang berkaitan dengan pendidikan, maka dapat disebutkan bahwa dari masing-masing UU tersebut terjadi pergeseran posisi pendidikan agama. Pergeseran tersebut dimulai dari UU Nomor 4 tahun 1950 Jo. UU nomor 14 Taun 1954 yang tidak mewajibkan pendidikan agama bagi siswa di sekolah, dan hanya mempersilakan orang tua/wali siswa untuk mengikuti atau tidak mengikuti pembelajaran agama. Pada UU Nomor 4 Tahun 1950, pendidikan bertujuan untuk membentuk manusia susila. Tafsiran yang berkembang, manusia susila dapat dicapai tidak hanya dengan agama, karena landasan untuk bersusila tidak selalu agama. Oleh karena itu pada dekade 1950 pelajaran agama tidak wajib atau tidak diharuskan untuk diajarkan di sekolah. Kondisi seperti ini tidak lain karena pengaruh Komunis di pemerintahan masih cukup kuat.

Tahap selanjutnya adalah lahirnya UU Nomor 2 Tahun 1989. Undang-Undang ini disebut sebagai UU yang jauh lebih maju dibanding UU sebelumnya. Pada UU tahun 1989 ini, pendidikan ditujukan untuk membentuk manusia seutuhnya yang beriman dan bertakwa kepada Tuhan Yang Maha Esa. Dari tujuan pendidikan yang seperti ini, meniscayakan dimasukkannya atau diwajibkannya pendidikan agama di sekolahsekolah. Lahirnya UU ini adalah hasil perjuangan bersama dari kalangan umat muslim yang serius, baik dari kalangan tokoh agama, politisi muslim, maupun birokrat muslim.

Pada tahun 2003 lahir UU Sisdiknas Nomor 20 yang di dalamnya semakin mempertegas eksistensi pendidikan agama. Lebih maju dari UU sebelumnya, UU ini mengamanatkan pendidikan agama wajib diberikan oleh semua lembaga pendidikan kepada peserta didik, dengan materi pelajaran agama yang sesuai dengan agama peserta didik, serta diajarkan oleh guru yang seagama, sehingga secara jelas tampak adanya pergeseran dari waktu ke waktu. Pergeseran sifat pendidikan dari yang semua non-konfessional menuju sifat yang konfessional.

\section{Daftar Pustaka}

An-Nahlawi, Abdurrahman, Ushulut at-Tarbiyat al-Islâmiyyah wa asalíbuha fi al-Bayt wa al-Madrasah wa al-Mujtama', Beirut: Dar al-Fikr, 1979.

Abernethy, David., Coombe, Trevor, "Education and Politics in Developing Countries", Harvard Educational Review 35(3):287-289.

Dhofier, Zamakhsyari, Tradisi Pesantren: studi pandangan hidup kyai dan visinya mengenai masa depan Indonesia, Jakarta: LP3ES, 2011.

Fadjar, A. Malik, Visi Pembaruan Pendidian Islam, Jakarta: Lembaga Pengembangan Pendidikan dan Penyususnan Naskah Indonesia, 1998.

Furqon, Arif, Pergeseran Sifat Konfessionalitas Pendidikan Nasional Indonesia, dalam Ulul Albab: jurnal studi Islam, sains, dan teknologi 5(1). Malang: Universitas Islam Negeri Malang, 2004

Gunawan, Ari H., Kebijakan-Kebijakan Pendidikan di Indonesia, Jakarta: Bina Aksara, 1986.

Geertz, Clifford, "The Javanese Kyai: The Changing Role of A Cultural Broker", dalam Comparative Studies in Society and History 2, 1959-1960. 
Jasin, Anwar, Pembaharuan Kurikulum Sekolah Dasar: Sejak Proklamasi Kemerdekaan, Jakarta: Balai Pustaka, 1987.

Kasiram, H.M., Mengenal Sistem Pendidikan Nasional Indonesia Menurut UUSPN no.2 tahun 1989, dalam Bahan Penataran P4 Pola Dukung 100 jam. Malang: IAIN Sunan Ampel, Fakultas Tarbiyah, 1993.

Kroef, van der, "Education in Indonesia", dalam Problems and Promises of Education in Asia, Amerika Serikat: Phi Delta Kappa International, $1957 . \quad$ (diakses 10 Septem-ber 2012).

Mahfudz MD, Moh., Politik Hukum Di Indonesia, Jakarta: PT Raja Grafindo Persada, 2012.

Budiardjo, Miriam, Dasat-Dasar Ilmu Politik, Jakarta: Gramedia Pustaka Utama, 2010 .

Moore, Basil, "The Nature of Religious Education”, dalam Graham M Rossiter Religious Education in Australian Schools. Canberra: Curriculum Develop-ment Center, 1981.

Nata, Abuddin, Kapita Selekta Pendidikan Islam, Jakarta: Penerbit Angkasa Bandung, 2003.

Dale, Roger, The State and Education Policy, Milton Keynes UK: Open University Press, 1989.

Samson, Alan, "Islam in Indonesia Politics", dalam Asian Survey (8):1001-1007.

Sirozi, Muhammad, Politik Kebijakan Pendidikan di Indonesia: peran tokohtokoh Islam dalam penyusunan UU No. 2 tahun 1989, Jakarta: INIS, 2004.

Sirozi, Muammad, Politik Pendidikan: dinamika hubungan antara kepentingagn kekuasaan dan praktik penyelenggaraan pendidikan, Jakarta: PT Raja Grafindo, 2010.
Soedijarto, Landasan dan Arah Pendidikan Nasional Kita, Jakarta: Penerbit Kompas, 2008.

Subhan, Arif, "Lembaga Pendidikan Islam Indonesia Abad Ke-20: Pergumulan antara Modernisasi dan Identitas", dalam Disertasi, Sekolah Pascasarjana Universitas Islam Negeri Syarif Hidayatullah Jakarta tahun 2007.

Surakhmad, Winarno dalam Sambutan pada buku Kaleidoskop Pendidikan Nasional. Kumpulan artikel HAR Tilaar, Jakarta: Kompas Media Nusantara, 2012.

Steenbrink, Karel A., Pesantren Madrasah Sekolah: pendidikan Islam dalam kurun modern, Jakarta: LP3ES, 1994.

Syam, Mohammad Noor, Filsafat Pendidikan dan Dasar Filsafat Pendidikan Pancasila, Surabaya: Usaha Nasional, 1988.

Thomas H. Eliot, Towards an Understanding of Public School Politics, dalam American Political Science Review 53(4):10321051, 1957.

Tilaar, H.A.R., Kekuasaan dan Pendidikan: manajemen pendidikan nasional dalam pusaran kekuasaan, Jakarta: Rineka Cipta, 2009.

Tilaar, H.A.R., Paradigma Baru Pendidikan Nasional, Jakarta: Rineka Cipta, 2002.

Tilaar, H.A.R., Pendidikan, Kebudayaan, dan Masyarakat Madani Indonesia Bandung: PT. Remaja Rosda Karya, 2002.

Undang-Undang Republik Indonesia Nomor 20 Tahun 2003 tentang Sistem Pendidikan Nasional.

Undang-Undang Nomor 4/1950 tentang Dasar Pendidikan dan Pengajaran.

Undang-Undang Republik Indonesia Nomor 2 Tahun 1989 Tentang Sistem Pendidikan Nasional. 
274 | TARBIYA | Vol. I, No.2, Desember 2014

Zainu'ddin, Ailsa, Education in the Netherlands East Indies and the Republic of Indonesia' dalam Selleck, R. J. W, Studies in Education, Melbourne: Melbourne University Press, 1970. 